\title{
MIR93 Pre-miRNA
}

National Cancer Institute

\section{Source}

National Cancer Institute. MIR93 Pre-miRNA. NCI Thesaurus. Code C82749.

MIR93 pre-miRNA is an olig oribonucleotide that is encoded by the human MIR93 gene

and has a role in the regulation of gene expression. 